\title{
EMILIN2 (Elastin microfibril interface located protein), potential modifier of thrombosis
}

\author{
Qila Sa and Jane L Hoover-Plow*
}

\begin{abstract}
Background: Elastin microfibril interface located protein 2 (EMILIN2) is an extracellular glycoprotein associated with cardiovascular development. While other EMILIN proteins are reported to play a role in elastogenesis and coagulation, little is known about EMILIN2 function in the cardiovascular system. The objective of this study was to determine whether EMILIN2 could play a role in thrombosis.

Results: EMILIN2 mRNA was expressed in 8 wk old C57BL/6J mice in lung, heart, aorta and bone marrow, with the highest expression in bone marrow. In mouse cells, EMILIN2 mRNA expression in macrophages was higher than expression in endothelial cells and fibroblasts. EMILIN2 was identified with cells and extracellular matrix by immunohistochemistry in the carotid and aorta. After carotid ferric chloride injury, EMILIN2 was abundantly expressed in the thrombus and inhibition of EMILIN2 increased platelet de-aggregation after ADP-stimulated platelet aggregation.
\end{abstract}

Conclusions: These results suggest EMILIN2 could play a role in thrombosis as a constituent of the vessel wall and/or a component of the thrombus.

\section{Background}

The clinical manifestations of arterial and venous thrombosis represent the leading causes of death in the developed world [1]. While arterial and venous thrombosis have fundamental pathobiological differences, both are complex [2] and are influenced by multiple genetic and environmental factors [3]. Acute thrombosis at the site of a plaque is thought to be a precipitating event in the transition from a stable or subclinical atherosclerotic disease to acute myocardial infarction, ischemic stroke or peripheral arterial occlusion. For individuals undergoing surgery, thromboembolism and venous thrombosis are common. Twin and sibling studies [4] show that inherited risk factors contribute significantly to the development of coronary artery disease and ischemic stroke. Genetic abnormalities that influence production, activity, or metabolism can shift the balance in favor of thrombosis. Polymorphisms [2,5] in coagulation factors, fibrinolytic factors, platelet surface receptors, methylenetetrahydrofolate reductase, endothelial nitric oxide

\footnotetext{
* Correspondence: hooverj@ccf.org

Joseph J. Jacobs Center For Thrombosis and Vascular Biology, Department of Cardiovascular Medicine and Department of Molecular Cardiology, Lerner Research Institute, Cleveland Clinic, Cleveland, OH 44195, USA
}

synthase and antioxidant enzymes have been implicated as genetic factors of risk for thrombosis. The role of many of these risk factors in thrombotic diseases has been replicated in animal models [6-11]. Great strides have been made in the diagnosis and treatment of thrombosis in the last decade. However, strategies to prevent thrombosis have lagged far behind, due in part to the contribution of multiple and as yet undefined genetic factors that lead to thrombotic risk. The objective of this study was to investigate whether EMILIN2 (elastin microfibril interface located protein 2), distributed in the cardiovascular system during development [12], plays a role in thrombosis.

The EMILIN proteins are a group of extracellular matrix multimeric glycoproteins [13] including EMILIN1, Multimerin1, Multimerin2 and EMILIN2. The EMILIN proteins share four protein domains (Figure 1): C-terminal C1q domain, collagenous domain, coiled-coil domain and $\mathrm{N}$-terminal cysteine-rich domain (EMI domain). The EMILIN proteins contain unique domains that are not shared: EMILIN1 has two leucine zipper regions; multimerin has an endothelial growth factor-like domain; and EMILIN2 contains a proline-rich domain. The domain organization suggests some shared and some specific

\section{(Ciomed Central}




\section{Emilin 2

EMI $\quad$ Coiled-coil $P$ COL $P$ C1q \\ Emilin 1

EMI Coiled-coil (LZ) COL C1q \\ Multimerin

EMI Coiled-coil CEF C1q

Figure 1 EMILIN Protein Domains. EMILIN2, EMILIN1 and Multimerin protein domains. Modified from Leimeister et al. [22] Grey: EMI (amino-terminal cysteine rich) domain; open: coiled-coil domain; light blue: P (proline-rich) domains; light grey: COL

(collagen) domain, and green: C1q (complement component 1, subcomponent q) domain.

functions for each of these EMILIN proteins. The proline-rich domain in EMILIN2 could provide structural flexibility and unique protein-protein interacting sites. EMILIN2 most closely resembles EMILIN1 [12], sharing $70 \%$ and $75 \%$ identity at the $\mathrm{N}$ - and C-terminal domains, respectively. Mouse EMILIN2 [12] has 73\% identity with human EMILIN2.

While little is known about the function of EMILIN2, functions have been identified for EMILIN1 and Multimerin1. The C1q domain is homologous to $\mathrm{C} 1 \mathrm{q}$ domains in a variety of proteins that are often involved in targeting proteins to cell surfaces and to other proteins [14]. $\mathrm{C} 1 \mathrm{q}$ is the target recognition domain of the classical pathway of complement activation and a connecting link between the innate and acquired immunity systems [15]. The C1q domains bind to form homo- and hetero-multimers. EMILIN2 can form heterotrimers with EMILIN1 and partially co-localizes with EMILIN1 in cell culture. EMILIN1 deficient mice [16] are fertile, growth rate is similar to wild-type mice, and they show no gross abnormalities. However, they have hypertension, deficits in elastogenesis, and defects of the lymphatic vasculature $[16,17]$. In addition to its role in vascular elastic fiber structure, EMILIN1 promotes cell adhesion and/or cell migration of several soft tissue sarcomas and hematopoietic cells [12]. Studies have reported that the EMILIN1 C1q domain mediates cell adhesion through $\alpha 4 \beta 1$ integrin [18]. Unlike other members of the EMILIN family, Multimerin contains an RGD site and binds to $\alpha I I \beta 3$ on platelets and $\alpha v \beta 3$ on endothelial cells [19]. Cell adhesion to immobilized Multimerin1 involves RGD-dependent and -independent mechanisms, depending on the cell type. The binding of endothelial cells, activated neutrophils and smooth muscle cells to Multimerin is not RGD dependent. In addition, Multimerin1 [20] is found as a complex with platelet factor $\mathrm{V}$ in platelet $\alpha$ granules and is released to the platelet surface upon platelet activation. It is also present in endothelial cells. The structural features of EMILIN1 and EMILIN2 suggest a unique, but related function for EMILIN2 in vascular homeostasis.

The major sites of expression of the EMILIN genes are in the cardiovascular system [21-23]. Other elastin associated binding proteins, including EMILIN1, fibulins and fibrillins $[24,25]$ are important for the integrity of the vessel wall structure. EMILIN1 deficiency causes disruptions of the endothelial cell layer and interruptions of the elastic lamellae of large vessels [16]. Fibulin1 binds to elastin and fibrinogen and is incorporated into fibrin clots and atherosclerotic plaques [16]; fibulin1 deficiency causes hemorrhaging due to the abnormal ECM; fibulin 5 deficient mice have altered vascular remodeling [26] and fibulin4 deficient mice $[26,27]$ are susceptible to aneurysm formation and aortic valve abnormalities. Hypertension is found in Emilin1 deficient mice and numerous studies indicate that hypertension is a risk factor for thrombosis. The association of these ECM proteins in the vascular wall with vascular remodeling after injury and hemostasis, implies that EMILIN2 may also share these functions and points to a potential role of EMILIN2 in thrombosis. The purpose of this study was to assess whether EMILIN2 plays a role in thrombosis.

The results of this study indicate that EMILIN2 does have the potential to regulate thrombosis. The major source of Emilin2 expression is the bone marrow. EMILIN2 is expressed in aorta, carotid artery wall, and ferric chloride-induced thrombi. In addition, inhibition of EMILIN2 causes de-aggregation of in vitro ADP-stimulated platelets. This study suggests EMILIN2 may be a modifier of thrombosis.

\section{Methods}

\section{Mice}

C57BL/6J mice (\#000664) were obtained from Jackson Laboratory (Bar Harbor, Maine) at 6 weeks of age. Mice were housed at the Biological Resource Unit at the Cleveland Clinic Lerner Research Institute. Mice were tested between 7 and 9 weeks of age. All animal experiments were performed in accordance with a protocol approved by the Institutional Animal Care and Use Committee at the Cleveland Clinic.

\section{Cells and cell culture}

The mouse cell lines, endothelial cells (EOMA), fibroblast cells (NIH3T3) and macrophage-like cells (Raw264.7) were purchased from the ATCC Global Biosource Centre (Manassas, VA). The cells were maintained according to the guidelines for each cell line in DMEM containing 10\% FBS (Invitrogen, Carlsbad, CA) at $37^{\circ} \mathrm{C}$ with $5 \% \mathrm{CO}_{2}$ and harvested at $90 \%$ confluence. Bone marrow was collected from the femurs and cells 
were harvested by centrifugation at $100 \times \mathrm{g}$ for $10 \mathrm{~min}$ then washed with PBS.

\section{RT-PCR and real-time PCR}

Total RNA was purified from the tissues and the cells using Qiagen RNeasy Mini Kit (Qiagen, Valencia, CA), treated with TURBO DNase (Ambion, Austin, TX) and reverse transcripted into cDNA using SuperScript ${ }^{\mathrm{TM}}$ III First-Strand Synthesis System for RT-PCR (Invitrogen, Carlsbad, CA) according to the manufacturer's instructions. RT-PCR was performed using $50 \mathrm{ng}$ cDNA from mice as templates. The PCR product was analyzed on $1 \%$ or $1.2 \%$ agarose gel and recovered by Qiaquick Gel Extraction Kit (Qiagen). Sequencing (ABI 3730xl, Applied Biosystems, Foster City, CA) was performed at the Genomics Core of Cleveland Clinic. Negative controls that omit reverse transcription were included. Real-time PCR was performed using a BioRad iCycler iQ (BioRad, Hercules, CA). Each amplification reaction contained $20 \mathrm{ng}$ of cDNA, $300 \mathrm{nM}$ of each primer, $25 \mu \mathrm{L}$ of $2 \times$ power SYBR Green Master Mix (Applied Biosystems, Warrington, UK), and $0.5 \mu \mathrm{L}$ of UNG (Applied Biosystems) added to prevent carryovers. Samples were normalized to glyceraldehyde-3-phosphate dehydrogenase (GAPDH, Operon, Huntsville, AL). The comparative cycle threshold method was used to analyze the data. RNA was isolated from 5-6 mice for each group and analyzed in triplicates.

\section{$\mathrm{FeCl}_{3}$ carotid injury and immunohistochemical staining}

To induce thrombus formation in the carotid artery, a ferric chloride $\left(\mathrm{FeCl}_{3}\right)$ model of vessel injury was employed as previously described [28]. The flow probe (Model 0.5PSB, Transonic Systems, Ithaca, NY) was in place from baseline measurements to several minutes after the stable occlusion had been reached, or stopped at $30 \mathrm{~min}$ if it had not occluded. Blood flow was recorded every $10 \mathrm{sec}$ (Model TS420, Transonic Systems). After cardiac perfusion, the carotid arteries were harvested after occlusion, immediately embedded into OCT (Tissue-Tek, Torrance, CA) and frozen. The frozen carotid arteries were sectioned at $10 \mu \mathrm{m}$ using a cryostat (Leica CM1850, Leica Microsystems, Nassloch, Germany), fixed with acetone at $4^{\circ} \mathrm{C}$ for $10 \mathrm{~min}$ then blocked with normal serum. EMILIN2 was detected with E185 (rabbit anti-peptide antibody, see additional files 1 and 2) or Q-16 (goat antibody, sc-51356, Santa Cruz Biotechnology, CA), and P-selectin with rabbit anti-CD62P antibody (BD biosciences, San Diego, CA). The sections were then incubated with 1:1000 diluted biotinylated appropriate secondary antibodies (PK-6101, PK-6105 Vectastain ABC Kit, Vector Laboratories, Burlingame, $\mathrm{CA}$ ) and proteins were visualized with alkaline phosphatase substrate. For quantification analysis, six sections of each carotid and six mice from each group were measured and analyzed using Image-Pro Plus (Media Cybernetics, Silver Spring, MD).

\section{Platelet aggregation assay}

Blood was collected into sodium citrate from the vena cava of anesthetized mice. The platelet rich plasma (PRP) was collected by centrifugation at $100 \times \mathrm{g}$ for $10 \mathrm{~min}$, and cell pellets were centrifuged at $1000 \times \mathrm{g}$ for 10 minutes to collect platelet poor plasma (PPP). Platelets were counted using a Cellometer Auto M10 (Nexcelom Bioscience, Lawrence, MA) and adjusted with PPP to $2-3 \times 10^{8} / \mathrm{ml}$. PRP was incubated with $26 \mu \mathrm{g} / \mathrm{ml}$ antiEMILIN2 antibody E185, or at a concentration as indicated, or control antibody (Calbiochem, La Jolla, CA) for 3 minutes at $37^{\circ} \mathrm{C}$ followed by the addition of 20 mM ADP (Chrono-log Corporation, Havertown, PA). Platelet aggregation was measured in an aggregometer (Chrono-log Corporation) and each sample was allowed to run for 8 minutes with stirring at $37^{\circ} \mathrm{C}$.

\section{Statistical analysis}

Differences between strains were determined by a t-test or ANOVA with a Newman-Kuels Multiple Comparison post-test. Data are presented as mean \pm SEM.

\section{Results}

\section{Distribution of Emilin2 mRNA in tissues}

The mRNA expression of Emilin2 was determined by quantitative real-time PCR in lung, heart, aorta and bone marrow cells (Figure 2A). The expression in the bone marrow was 20 -fold higher than in the lung. This suggests that bone marrow is a major source of Emilin2 and is unlike Emilin1 expression [21] where the major source is the vessel wall.

Expression of Emilin2 was tested in a mouse macrophage-like cell line (Raw264.7), and two other cell types associated with vascular wall, a mouse endothelial cell line (EOMA), and a mouse fibroblast cell line (NIH3T3). The relative expression in macrophage cells was comparable to expression in mouse bone marrow cells (Figure 2B). The expression of Emilin2 was 7-, 32- and 26-fold higher in NIH3T3, Raw264.7 and bone marrow cells, respectively, compared to EOMA cells suggesting that the expression of Emilin 2 may be high in hematopoietic progenitor stem cells, precursors for white and red blood cells and platelets.

\section{EMILIN2 was expressed in the vessel wall and in the thrombus induced by vascular injury}

EMILIN2 was detected in the vessel wall of uninjured carotids (Figure 3A, B). The immunostaining was 55\% \pm 2 of the vessel wall area (Figure 3G, gray bar). EMILIN2 was detected in both cells and extracellular matrix. The 
A.

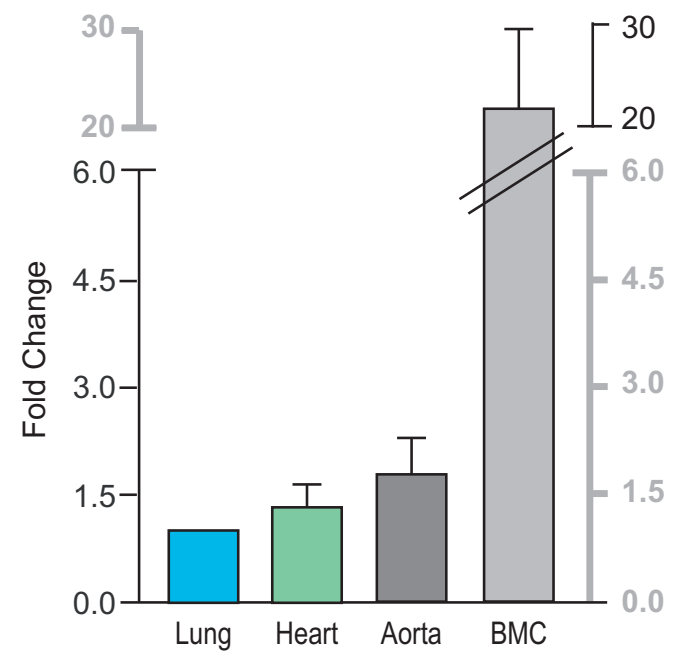

B.

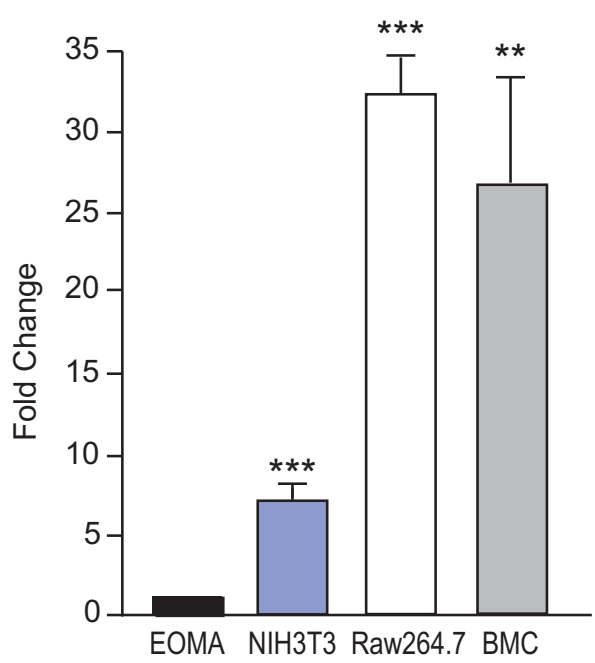

Figure 2 Emilin2 mRNA Expression in Tissues and Mouse Cells. GAPDH from the same cDNA samples used as endogenous control. A Expression of Emilin2 in lung, heart, aorta and bone marrow cells was determined by real-time PCR. Aorta, $n=3 ;$ others, $n=5$. The $m R N A$ levels are presented as fold change relative to lung. The values are mean \pm SEM $n=3-5$. B. Expression of Emilin2 in mouse cell lines. The mRNA levels are presented as fold change relative to EOMA. EOMA, mouse endothelial cell line; NIH3T3, mouse fibroblast cell line; Raw264.7, mouse macrophage-like cell line. The values are mean \pm SEM of 3 independent experiments. Statistical differences compared to EOMA were determined by ANOVA and Newman-Kuels post-test. ${ }^{*} P<0.01,{ }^{* *} P<0.001$.

aorta clearly defines the sites of Emilin2 (see additional file 3). To determine if EMILIN2 protein is incorporated into the thrombus, $\mathrm{FeCl}_{3}$ was used to induce thrombus formation in the carotid artery. After injury, carotid arteries were harvested and immunostained for EMILIN2 (Figure 3C, D). Strong $(77 \% \pm 2$ ) (Figure 3G open bar) EMILIN2-specific staining was detected in thrombi, suggesting that EMILIN2 is associated most strongly with the thrombus rather than the vessel wall. This is consistent with the mRNA expression in the bone marrow cells, platelet, and plasma protein expression. No signal was detected in the sections stained with rabbit IgG or pre-immune rabbit serum. The staining of EMILIN2 in thrombi was confirmed by using the commercial EMILIN2 Q-16 antibody (Figure 3E).

The high expression of EMILIN2 in bone marrow and in the thrombi raised the question whether EMILIN2 was involved in platelet function. Therefore, carotid sections were also immunostained for P-selectin (Figure 3F), one of the platelet markers. Strong immunostaining (Figure $3 \mathrm{G}$, black bar) for P-selectin $(88 \% \pm 1$ of thrombi area) revealed a similar distribution pattern to that found for EMILIN2 (77\% of thrombi area) in the injured carotids.

\section{EMILIN2 antibody inhibits platelet aggregation}

The similar relative distribution of EMILIN2 and platelets in the thrombi suggested that EMILIN2 may regulate clot stability through a role in platelet aggregation. Preincubation of platelets with anti-EMILIN2 antibody inhibited the extent and rate of platelet aggregation induced by ADP (Figure 4A). Pre-incubation of platelets with EMILIN2 antibody inhibited the maximum amplitude of platelet aggregation by approximately $42 \%$ (Figure 4B). Moreover, the EMILIN2 antibody caused platelet deaggregation in the presence of high ADP concentrations $(20 \mu \mathrm{M})$ over induction time (Figure $4 \mathrm{C})$. At 7 minutes after addition of $20 \mu \mathrm{M}$ ADP, platelet de-aggregation in the presence of the antibody was inhibited by $90 \%$. Inhibition of ADP-induced platelet aggregation by EMILIN2 antibody was dose dependent, with the highest inhibition achieved at $26 \mu \mathrm{g} / \mathrm{ml}$ (Figure 4D). These data suggest that EMILIN2 functions in stabilizing aggregated platelets.

\section{Discussion}

In this study we report evidence that EMILIN2 may play a role in thrombosis. EMILIN2 mRNA expression is high in bone marrow and higher in macrophages than endothelial cells or fibroblasts The protein distribution of EMILIN2 in thrombi was similar to P-selectin, a marker for platelets suggesting EMILIN2 may be associated with platelets. Further, EMILIN2 antibody increased platelet de-aggregation. EMILIN2 could play a role in thrombosis by maintaining the vessel wall architecture as a component of vessel wall or in the regulation of the platelet aggregation stability by virtue of its presence in plasma and platelets. This is the first report of in vivo protein expression of EMILIN2 in adult tissues and to 


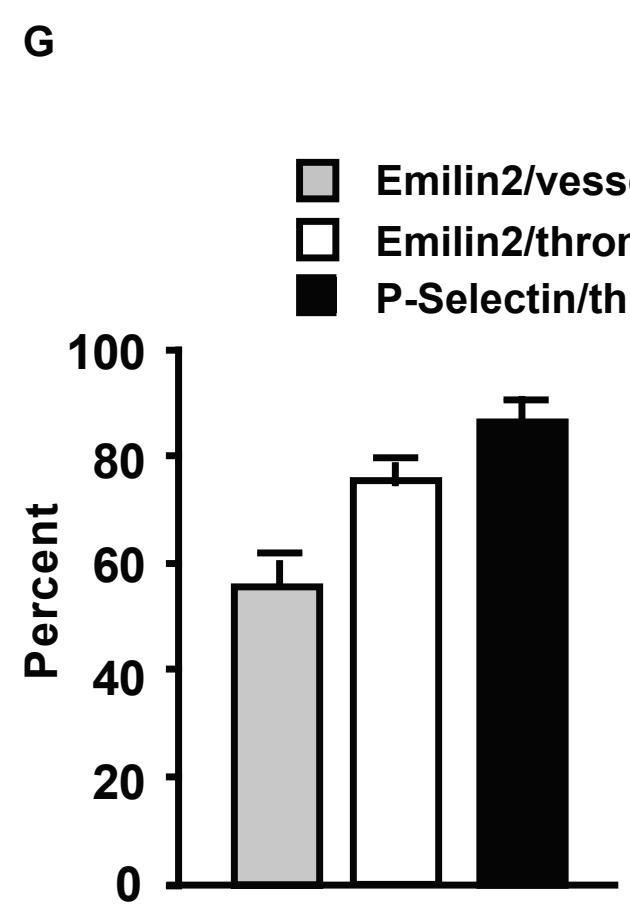

Figure 3 Localization of EMILIN2 in carotids. A, B. Sections from uninjured carotid were immunostained with E185 for EMILIN2. C, D, E. Ferric chloride induced vascular injury. Sections were immunostained with C. E185, D. Q-16, or F. P-selectin antibody. A, C, E, F. Magnification $\times 100$ and B, D. $\times$ 400. G. Quantification of immunostaining. The values are mean \pm SEM of the percent of EMILIN2 (E185)/vessel wall, EMILIN2 (E185)/ thrombus area and P-selectin/thrombus area of 6 mice per strain. Six sections per mouse were analyzed for each mouse using Image-Pro Plus software. Modified from Sa et al [Mamm Genome 2010 21:337-349].

provide evidence for a potential role of EMILIN2 in thrombosis.

While EMILIN2 has a high homology to EMILIN1 and the molecular structures of EMILIN1 and EMILIN2 are similar, there are distinctive molecular differences between the two proteins. In addition, the pattern of mRNA expression in embryonic development [21] is different between EMILIN1 and EMILIN2 and the expression pattern is also different in adults [21]. The differences in molecular structure and expression suggest the proteins have different functions. On the other hand, there are similarities as well. EMILIN2 and EMILIN1 are extracellular matrix proteins and are found in the vasculature. EMILIN1 deficiency disrupts the structure of the vascular wall and impairs elastogenesis. A deficiency of other microfibril and elastin associated molecules also disrupt elastogenesis, including fibrillin-1, fibrillin-2, microfibril associated glycoprotein 1 (MAGP1) [29] and the fibulins 1-5 [21-26,30,31]. Fibulin 4 heterozygous mice (the null mutation is lethal) have prolonged clot stability in the tail-bleeding/rebleeding assay (Hoover-Plow, J and Chen, Q, unpublished results). MAGP1 deficient mice have delayed thrombotic occlusion after vascular injury [29]. To determine whether EMILIN2 plays an important role in vascular structure and response to vascular injury will require the construction of genetically modified mice.

Platelet may be a site producing or storing EMILIN2. Multimerin1, another EMILIN protein, is stored in the platelet alpha granules bound to Factor $\mathrm{V}$ and is released upon platelet activation [20]. EMILIN2 could be a component of platelet alpha granules or alternatively, plasma EMILIN2 could bind to the platelets and exert an effect on thrombus stability. Factor V, a cofactor needed for thrombin generation, is present in both plasma and platelets and may be taken up by the platelets [19].

All adult tissues that have been tested contain EMILIN2, cochlear basement membrane [32], brain, spleen, liver [33] and heart $[34,35]$. This would be expected of an ECM protein. In addition, a number of proteomic and microarray studies of human tissues (Table 1) have identified EMILIN2 in extracellular fluids (plasma, synovial, amniotic and seminal plasma), stem cells (hematopoietic, mesenchymal, osteoblasts), stimulated endometrial stromal cells, cancer cells (hepatic, lymphocytic leukemia, colorectal cancer, and ovarian cancer), and as a cell surface marker for human embryonic stem cell-derived cardiomyocytes [36-50]. A recent study [40] reported down-regulation of EMILIN2 in brain arteriovenous malformations. These 


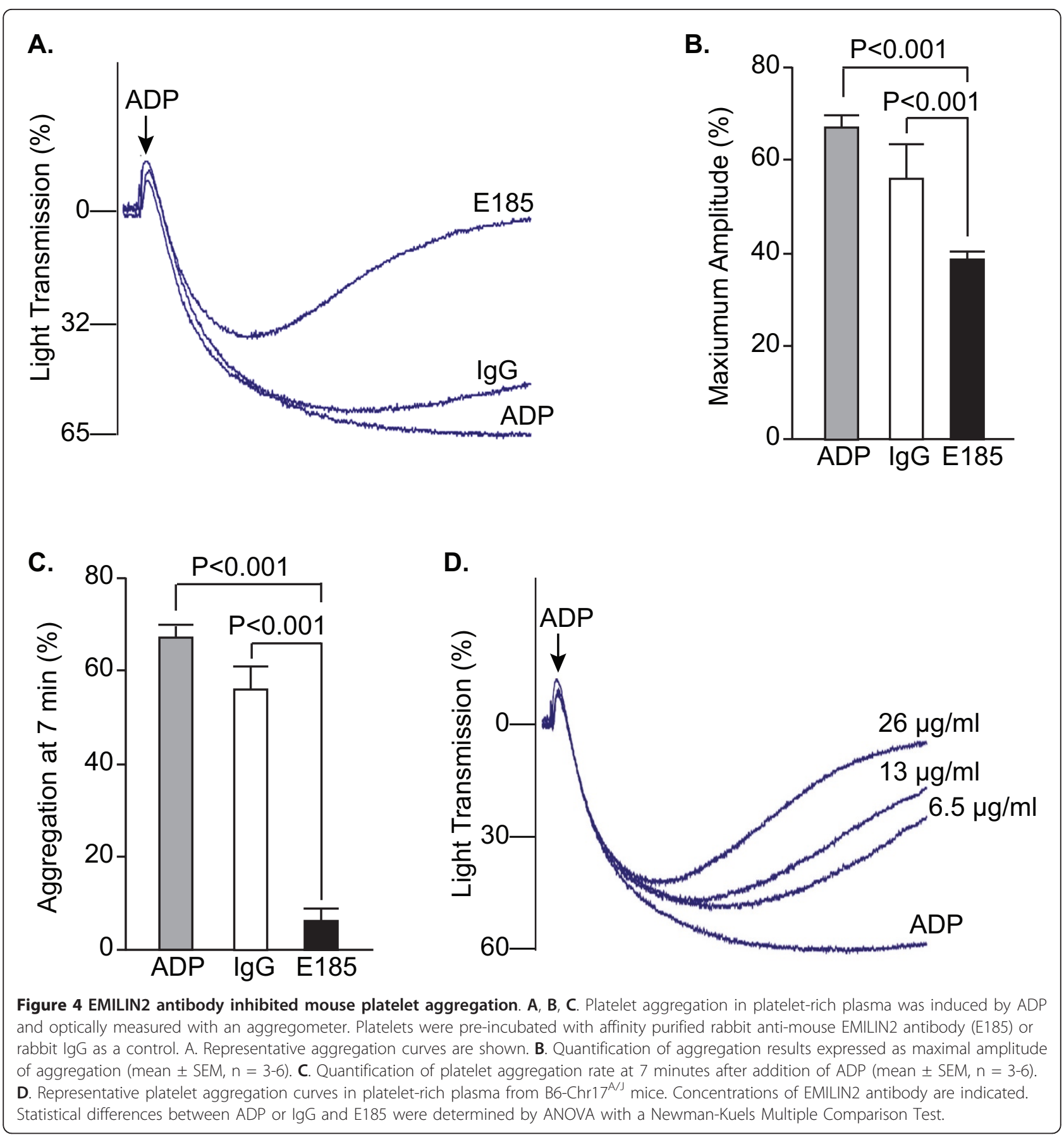

studies suggest EMILIN2 plays important physiological and pathological roles. The identification of EMILIN2 in plasma in humans as well as a component of mouse thrombus supports the hypothesis that EMILIN2 could play a role in thrombosis.

\section{Conclusions}

In this study, we found EMILIN2 expression in mouse lung, heart, aorta, and bone marrow. Protein expression in the carotid vessel wall and thrombi suggesting EMILIN2 could function directly in the thrombus and/or as a constituent of the vessel wall. EMILIN2 was identified in humans in plasma/serum, amniotic fluid, seminal plasma, stem cells, cancer cells, and heart stem cells suggesting EMILIN2 may play important physiological/pathological roles. Further studies, are needed to identify the role of EMILIN2 in platelet aggregation. 
Table 1 EMILIN2 expressed in human tissues

\begin{tabular}{|c|c|}
\hline Tissue & Reference \\
\hline Plasma/serum^ & [36] \\
\hline Amniotic fluid^ & [37] \\
\hline Seminal plasma^ & [38] \\
\hline RA synovial fluid^ & [39] \\
\hline Decreased expression in brain arteriovenous malformations* & [40] \\
\hline Increased in granulocytes after G-CSF treatment* & [41] \\
\hline Increased in mesenchymal stem cells* & {$[42]$} \\
\hline Osteoblast ECM matrix vesicles^ & [43] \\
\hline Decreased in endometrial stromal cells treated with CAMP* & [44] \\
\hline Hepatic carcinoma cells* & [45] \\
\hline Hepatic carcinoma cells^ & [46] \\
\hline Chronic lymphocytic leukemia cells* & [47] \\
\hline Colorectal cancer nuclear matrix $\wedge$ & [48] \\
\hline Fragments in sera of patients with ovarian cancer^ & {$[49,50]$} \\
\hline Human embryonic stem cell-derived cardiomyocytes^ & [34] \\
\hline
\end{tabular}

$\wedge$ - protein expression; * - mRNA expression

\section{Additional material}

\section{Additional file 1: Figure 1: EMILIN2 peptide for antibody}

generation. In order to measure EMILIN2 protein and to study its functions, a polyclonal antibody for mouse EMILIN2 was generated in rabbits. Since EMILIN2 has a high homology to EMILIN1, a peptide was synthesized from residues 829-843 located in the proline-rich domain specific to EMILIN2 (see additional file 1). To increase the specificity of the antibody, the rabbit antiserum was subjected to affinity-purification using the peptide.

Additional file 2: Figure 2: EMILIN2 antibody specificity. To test the specificity of the antibody, HEK293 cells were transfected with the construct E2-N1 that contains the EMILIN2-EGFP fusion gene and construct PR-N1 that harbors the PR domain-EGFP fusion gene. The vector $\mathrm{N} 1$ that contains only the EGFP gene was used as negative control. Constructs containing EMILIN2 protein domains, namely Collagen-like C1q domains that do not interact with the antibody, and EGFP fusion genes, were also used as negative controls.

Additional file 3: Figure 3: EMILIN2 Immunostaining of aorta. After cardiac perfusion, the aortas were harvested, immediately embedded into OCT (Tissue-Tek, Torrance, CA) and frozen. The frozen aortas were sectioned at $10 \mu \mathrm{m}$ using a cryostat (Leica CM1850, Leica Microsystems, Nassloch, Germany), fixed with acetone at $4^{\circ} \mathrm{C}$ for 10 min then blocked with normal serum. EMILIN2 was detected with E185 antibody. The section was then incubated with 1:1000 diluted biotinylated appropriate secondary antibodies (PK-6101, PK-6105 Vectastain ABC Kit, Vector Laboratories, Burlingame, CA) and EMILIN2 visualized (brown color) with alkaline phosphatase substrate.

\section{Acknowledgements}

The authors thank Robin Lewis for assistance with preparation of the manuscript. This study was supported by grants from NIH, HL065204, HL078701 (JHP), and American Heart Association, 0825602D (QS).

\section{Authors' contributions}

QS performed experiments, analyzed data, and participated in writing the paper. JHP designed and planned the study, analyzed data, and wrote the paper. Both authors have read and approved the final manuscript.

\section{Competing interests}

The authors declare that they have no competing interests.
Received: 9 March 2010 Accepted: 11 May 2011 Published: 11 May 2011

\section{References}

1. Ross R: Atherosclerosis - An inflammatory disease. N Engl J Med 1999, 340:115-26.

2. Voetsch B, Loscalzo J: Genetic determinants of arterial thrombosis Arterioscler Thromb Vasc Biol 2004, 24:216-229.

3. Humphries SE, Lane A, Dawson S, Green FR: The study of geneenvironment interactions that influence thrombosis and fibrinolysis. Genetic variation at the loci for factor VII and plasminogen activator inhibitor-1. Arch Pathol Lab Med 1992, 116:1322-1329.

4. Marenberg ME, Risch N, Berman LF, Floderus B, de Faire U: Genetic susceptibility to death from coronary heart disease in a study of twins. N Engl J Med 1994, 330:1041-1046.

5. Lusis AJ, Fogelman AM, Fonarow GC: Genetic basis of atherosclerosis: Part II. Clinical implications. Circulation 2004, 110:2066-2071.

6. Westrick RJ, Eitzman DT: Plasminogen activator inhibitor-1 in vascular thrombosis. Curr Drug Targets 2007, 8:966-1002.

7. Cui J, Eitzman DT, Westrick RJ, Christie PD, Xu ZJ, Yang AY, Purkayastha AA, Yang TL, Metz AL, Gallagher KP, Tyson JA, Rosenberg RD, Ginsburg D: Spontaneous thrombosis in mice carrying the factor $\mathrm{V}$ Leiden mutation. Blood 2000, 96:4222-4226.

8. D'Andrea D, Ravera M, Golino P, Rosica A, De Felice M, Ragni M, Cirillo P, Vigorito F, Corcione N, Tommasini P, Gargiulo A, Piro O, Calabro P, Chiariello M: Induction of tissue factor in the arterial wall during recurrent thrombus formation. Arterioscler Thromb Vasc Biol 2003, 23:1684-1689.

9. Eren M, Painter CA, Atkinson JB, Declerck PJ, Vaughan DE: Age-dependent spontaneous coronary arterial thrombosis in transgenic mice that express a stable form of human plasminogen activiator inhibitor-1. Circulation 2002, 106:491-496.

10. C Li TT, Larrucea S, Souza S, Leal SM, Lopez JA, Rubin EM, Nieswandt B, Bray PF: Genetic variation responsible for mouse strain differences in integrin alpha 2 expression is associated with altered platelet responses to collagen. Blood 2004, 103:3396-3402.

11. Sha J, McCullough B, Hart E, Nassir F, Davidson NO, Hoover-Plow J: Apo(a) promotes thrombosis in a vascular injury model by a mechanism independent of plasminogen. J Thromb Haemost 2005, 3:2281-2289.

12. Doliana R, Bot S, Mungiguerra G, Canton A, Cilli SP, Colombatti A: Isolation and characterization of EMILIN-2, a new component of the growing EMILINs family and a member of the EMI domain-containing superfamily. J Biol Chem 2001, 276(15):12003-12011.

13. Colombatti A, Doliana R, Bot S, Canton A, Mongiat M, Mungiguerra G, Paron-Cilli S, Spessotto P: The EMILIN protein family. Matrix Biol 2000 19:289-301.

14. Tom TY, Hu T, Arterburn M, Boyle B, Bright JM, Palencia S, Emtage PC, Funk WD: The complete complement of C1q-domain-containing proteins in Homo sapiens. Genomics 2005, 86:100-111.

15. Hayward CP, Hassell JA, Denomme GA, Rachubinski RA, Brown C, Kelton JG: The CDNA sequence of human endothelial cell multimerin. A unique protein with RGDS, coiled-coil, and epidermal growth factor-like domains and a carboxyl terminus similar to the globular domain of complement C1q and collagens type VIII and X. J Biol Chem 1995, 270:18246-18251.

16. Zanetti M, Braghetta P, Sabatelli P, Mura I, Doliana R, Colombatti A, Volpin D, Bonaldo P, Bressan GM: EMILIN-1 deficiency induces elastogenesis and vascular cell defects. Mol Cell Biol 2004, 24:638-650.

17. Danussi C, Spessotto P, Petrucco A, Wassermann B, Sabatelli P, Montesi M, Doliana R, Bressan GM, Colombatti A: Emilin1 deficiency causes structural and functional defects of lymphatic vasculature. Mol Cell Biol 2008, 28:4026-4039.

18. Spessotto P, Cervi M, Mucignat MT, Mungiguerra G, Sartoretto I, Doliana R, Colombatti A: beta 1 Integrin-dependent cell adhesion to EMILIN-1 is mediated by the gC1q domain. J Biol Chem 2003, 278:6160-6167.

19. Hayward CP, Fuller N, Zheng S, Adam F, Jeimy SB, Horsewood I, QuinnAllen MA, Kane WH: Human platelets contain forms of factor $\mathrm{V}$ in disulfide-linkage with multimerin. Thromb Haemost 2004, 92:1349-1357.

20. Mann KG, Kalafatis M: Factor V: a combination of Dr Jekyll and Mr Hyde. Blood 2003, 101:20-30. 
21. Braghetta P, Ferrari A, De GP, Zanetti M, Volpin D, Bonaldo P, Bressan GM: Overlapping, complementary and site-specific expression pattern of genes of the EMILIN/Multimerin family. Matrix Biol 2004, 22:549-56.

22. Leimeister C, Steidl C, Schumacher N, Erhard S, Gessler M: Developmental expression and biochemical characterization of Emu family members. Dev Biol 2002, 249:204-218

23. Milanetto M, Tiso N, Braghetta P, Volpin D, Argenton F, Bonaldo P: Emilin genes are duplicated and dynamically expressed during zebrafish embryonic development. Dev Dyn 2008, 237:222-232.

24. Kielty CM, Sherratt MJ, Shuttleworth CA: Elastic fibres. J Cell Sci 2002, 115:2817-2828.

25. Tran H, Tanaka A, Litvinovich SV, Medved LV, Haudenschild CC, Argraves WS: The interaction of fibulin-1 with fibrinogen. A potential role in hemostasis and thrombosis. J Biol Chem 1995, 270:19458-19464.

26. McLaughlin PJ, Chen Q, Horiguchi M, Starcher BC, Stanton JB, Broekelmann TJ, Marmorstein AD, McKay B, Mecham R, Nakamura T, Marmorstein LY: Targeted disruption of fibulin-4 abolishes elastogenesis and causes perinatal lethality in mice. Mol Cell Biol 2006, 26:1700-1709.

27. Hanada K, Vermeij M, Garinis GA, de Waard MC, Kunen MG, Myers L, Maas A, Duncker DJ, Meijers C, Dietz HC, Kanaar R, Essers J: Perturbations of vascular homeostasis and aortic valve abnormalities in fibulin-4 deficient mice. Circ Res 2007, 100:738-746.

28. Hoover-Plow J, Shchurin A, Hart E, Sha J, Hill AE, Singer JB, Nadeau JH: Genetic background determines response to hemostasis and thrombosis. BMC Blood Disord 2006, 6:6

29. Werneck CC, Vicente CP, Weinberg JS, Shifren A, Pierce RA, Broekelmann TJ, Tollefsen DM, Mecham RP: Mice lacking the extracellular matrix protein MAGP1 display delayed thrombotic occlusion following vessel injury. Blood 2008, 111:4137-4144.

30. Robinson PN, Godfrey M: The molecular genetics of Marfan syndrome and related microfibrillopathies. J Med Genet 2000, 37:9-25.

31. Hirai M, Ohbayashi T, Horiguchi M, Okawa K, Hagiwara A, Chien KR, Kita T, Nakamura T: Fibulin-5/DANCE has an elastogenic organizer activity that is abrogated by proteolytic cleavage in vivo. J Cell Biol 2007, 176:1061-1071.

32. Amma LL, Goodyear R, Faris JS, Jones I, Ng L, Richardson G, Forrest D: An emilin family extracellular matrix protein identified in the cochlear basilar membrane. Mol Cell Neurosci 2003, 23:460-472.

33. Campbell CD, Kirby A, Nemesh J, Daly MJ, Hirschhorn JN: A survey of allelic imbalance in F1 mice. Genome Res 2008, 18:555-563.

34. VanHoof D, Dormeyer W, Braam SR, Passier R, Monshouwer-Kloots J, Wardvan Oostwaard, Heck AJR, Krijgsveld J, Mummery CL: Identification of cell surface proteins for antibody-based selection of human embryonic stem cell-dervived cardiomyocytes. J Proteome Res 2010, 9:1610-1618.

35. Remme CA, Scicluna BP, Verkerk AO, Amin AS, van Brunschot S, Beekman L, Deneer VH, Chevalier C, Oyama F, Miyazaki H, Nukina N, Wilders R, Escande D, Houlgatte R, Wilde AA, Tan HL, Veldkamp MW, de Bakker JM, Bezzina CR: Genetically Determined Differences in Sodium Current Characteristics Modulate Conduction Disease Severity in Mice With Cardiac Sodium Channelopathy. Circ Res 2009, 104:1283-1292.

36. Omenn GS, States DJ, Adamski M, Blackwell TW, Menon R, Hermjakob H, Apweiler R, Haab BB, Simpson RJ, Eddes JS, Kapp EA, Moritz RL, Chan DW, Rai AJ, Admon A, Aebersold R, Eng J, Hancock WS, Hefta SA, Meyer H, Paik YK, Yoo JS, Ping P, Pounds J, Adkins J, Qian X, Wang R, Wasinger V, Wu CY, Zhao X, Zeng R, Archakov A, Tsugita A, Beer I, Pandey A, Pisano M, Andrews $\mathrm{P}$, Tammen H, Speicher DW, Hanash SM: Overview of the HUPO Plasma Proteome Project: results from the pilot phase with 35 collaborating laboratories and multiple analytical groups, generating a core dataset of 3020 proteins and a publicly-available database. Proteomics 2005, 5:3226-3245.

37. Cho CK, Shan SJ, Winsor EJ, Diamandis EP: Proteomics analysis of human amniotic fluid. Mol Cell Proteomics 2007, 6:1406-1415.

38. Pilch B, Mann M: Large-scale and high-confidence proteomic analysis of human seminal plasma. Genome Biol 2006, 7:R40.

39. Cano L, Arkfeld DG: Targeted synovial fluid proteomics for biomarker discovery in rheumatoid arthritis. Clin Proteom 2010, 5:75-102.

40. Sasahara A, Kasuya H, Akagawa $H$, Ujiie H, Kubo O, Sasaki T, Onda H, Sakamoto Y, Krischek B, Hori T, Inoue I: Increased expression of ephrin A1 in brain arteriovenous malformation: DNA microarray analysis. Neurosurg Rev 2007, 30:299-305.
41. Drewniak A, van Raam BJ, Geissler J, Tool AT, Mook OR, van den Berg TK, Baas F, Kuijpers TW: Changes in gene expression of granulocytes during in vivo granulocyte colony-stimulating factor/dexamethasone mobilization for transfusion purposes. Blood 2009, 113:5979-5998.

42. Liu TM, Wu YN, Guo XM, Hui JH, Lee EH, Lim B: Effects of ectopic Nanog and Oct4 overexpression on mesenchymal stem cells. Stem Cells Dev 2009, 18:1013-1022.

43. Xiao Z, Camalier CE, Nagashima K, Chan KC, Lucas DA, De La Cruz MJ, Gignac M, Lockett S, Issaq HJ, Veenstra TD, Conrads TP, Beck GR: Analysis of the Extracellular Matric Vesicle Proteiome in mineralizing osteoblasts. J Cell Physiol 210:325-335.

44. Aghajanova L, Horcajadas JA, Weeks JL, Esteban FJ, Nezhat CN, Conti M, Giudice LC: The protein kinase A pathway-regulated transcriptome of endometrial stromal fibroblasts reveals compromised differentiation and persistent proliferative potential in endometriosis. Endocrinology 2010, 151:1341-1355.

45. Huang J, Zheng DL, Qin FS, Cheng N, Chen H, Wan BB, Wang YP, Xiao HS, Han ZG: Genetic and epigenetic silencing of SCARA5 may contribute to human hepatocellular carcinoma by activating FAK signaling. J Clin Invest 2010, 120:223-241

46. Chaerkady R, Harsha HC, Nalli A, Gucek M, Vivekanandan P, Akhtar J, Cole RN, Simmers J, Schulick RD, Singh S, Torbenson M, Pandey A, Thuluvath PJ: A quantitative proteomic approach for identification of potential biomarkers in hepatocellular carcinoma. J Proteome Res 2008, 7:4289-4298.

47. Schwaenen C, Nessling M, Wessendorf S, Salvi T, Wrobel G, Radlwimmer B, Kestler HA, Haslinger C, Stilgenbauer S, Dohner H, Bentz M, Lichter P: Automated array-based genomic profiling in chronic lymphocytic leukemia: development of a clinical tool and discovery of recurrent genomic alterations. Proc Natl Acad Sci USA 2004, 101:1039-1044.

48. Albrethsen J, Knol JC, Piersma S, Pham TV, de WM, Mongera S, Carvalho B, Verheul HM, Fijneman RJ, Meijer GA, Jimenez CR: Sub-nuclear proteomics in colorectal cancer:Identification of proteins enriched in the nuclear matrix fraction and regulation in adenoma to carcinoma progression. Mol Cell Proteomics 2010, 9:988-1005.

49. Scholler N, Gross JA, Garvik B, Wells L, Liu Y, Loch CM, Ramirez AB, McIntosh MW, Lampe PD, Urban N: Use of cancer-specific yeast-secreted in vivo biotinylated recombinant antibodies for serum biomarker discovery. J Transl Med 2008, 6:41.

50. Salani R, Neuberger I, Kurman RJ, Bristow RE, Chang HW, Wang TL, Shih IM: Expression of extracellular matrix proteins in ovarian serous tumors. Int $J$ Gynecol Pathol 2007, 26:141-146.

doi:10.1186/1477-9560-9-9

Cite this article as: Sa and Hoover-Plow: EMILIN2 (Elastin microfibril interface located protein), potential modifier of thrombosis. Thrombosis Journal 2011 9:9.

\section{Submit your next manuscript to BioMed Central and take full advantage of:}

- Convenient online submission

- Thorough peer review

- No space constraints or color figure charges

- Immediate publication on acceptance

- Inclusion in PubMed, CAS, Scopus and Google Scholar

- Research which is freely available for redistribution

Submit your manuscript at www.biomedcentral.com/submit
C Biomed Central 